Article

\title{
A Landscape-Scale Adjoining Conservation (LAC) Approach for Efficient Habitat Expansion: The Case of Changbai Mountain, Northeast China
}

\author{
Jianwei Bai ${ }^{1,2}$, Lina Tang ${ }^{3, *(\mathbb{D})}$, Qingchun Wang ${ }^{4}$ and Fengri $\mathrm{Li}^{1, *(\mathbb{D})}$ \\ 1 School of Forestry, Northeast Forestry University, Harbin 150040, China; bjw@foxmail.com \\ 2 State Forestry Administration, Beijing 100714, China \\ 3 Key Lab of Urban Environment and Health, Institute of Urban Environment, Chinese Academy of Sciences, \\ Xiamen 361021, China \\ 4 College of Nature Conservation, Beijing Forestry University, Beijing 100083, China; wangqch96@aliyun.com \\ * Correspondence: Intang@iue.ac.cn (L.T.); fengrili@126.com (F.L.); Tel.: +86-592-6190681 (L.T.); \\ $+86-13503637477$ (F.L.)
}

Received: 12 July 2018; Accepted: 14 August 2018; Published: 17 August 2018

check for updates

\begin{abstract}
The biodiversity crisis and ecosystem degradation caused by habitat destruction and human activities can be reduced by organizing protected areas. However, many protected areas currently take the form of "green islands," which has led to serious habitat isolation in many places. We thus introduce herein a landscape-scale adjoining conservation (LAC) approach for the protection and restoration of ecosystems across the boundaries between protected areas and surrounding non-protected areas. The strategy of the LAC approach is to effectively expand conservation areas by connecting isolated areas of important ecosystems or habitats outside of protected areas. The methodology of the LAC approach involves integrated analyses that consider both habitat quality and landscape patterns. Forest-habitat quality is characterized by species composition and stand structure, and habitat connectivity is quantified by the max patch area of habitat and total habitat area. The focal statistic is useful for examining habitat clumps that result from landscape fragmentation. As a case study, we apply the LAC approach to adjoining restoration of broadleaf Korean pine mixed forest on the Changbai Mountain in northeastern China. We developed a metric called the Restoration Efficiency of Landscape Expansion (RELE) to evaluate the LAC approach. The results indicate that a minimal restoration effort can produce significant effects in terms of the expansion of contiguous habitat, as quantified by RELE.
\end{abstract}

Keywords: biodiversity; ecosystem protection; habitat fragmentation; habitat expansion; landscape pattern; adjoining conservation; sustainable management

\section{Introduction}

The success in biodiversity conservation requires the protection of both individual species and enough habitat area [1]. Hansson and Angelstam [2] proposed the potentials of landscape ecology studies for a better understanding of nature conservation at the early stage of landscape ecology. Franklin [3] suggested that an in-depth understanding and proper management of habitat landscape as a whole is important to controlling habitat connectivity and maintaining diversity. Andrén [4] argued that habitat fragmentation reduces the original habitat area, shrinks habitat patches, increases the distance between habitats, and the emergence of new types of habitat. Because numerous species need protection, many of which are still unknown, efforts in biodiversity conservation should focus on protecting ecosystems and landscapes as opposed to simply protecting a given species. This idea has 
become parts of national biodiversity strategies and action plans under the Convention on Biological Diversity [5].

Since the beginning of the 20th century, the debate about habitat destruction and species protection has become increasingly intense and extensive and has led now to several commonly accepted principles. For example, it is now accepted that corridors between forest patches provide continuity of animal habitat and should receive primary protection [6]. Both habitat loss and fragmentation are now understood to play important roles in the extinction of species, therefore efforts should be made to avoid habitat loss, and strengthen habitat restoration [7,8]. Human activities have destroyed the habitat of innumerable species, and thereby accelerated their extinction, so we must now be vigilant in protecting the remaining landscapes and ecological processes [9]. The decrease in native vegetation cover and changes in land use are the decisive factors in species extinction, especially for indicator species [10]. Although this biodiversity crisis caused by habitat destruction and human pressure can be reduced by constructing protected areas, the current amount of protected areas worldwide remains far from sufficient [11]. Thus, one of the greatest challenges we face to effectively conserve biodiversity is to find methods to increase the amount and quality of protected areas.

It is crucial to connect protected areas for meeting their conservation goals [5]. Researchers typically use the term trans-boundary or trans-border protection to describe two or more protected areas that span across legal or administrative boundaries and the cooperative management of such areas to conserve biodiversity in addition to natural and cultural resources [12]. A total of 59 such trans-boundary protected areas (TPAs) had been developed by 1988, and 227 by 2007 [13]. The earlier TPAs were mainly in Europe and Africa, but they have become popular in Asia since 2005 [14].

Kark et al. [15] addressed a wide range of strategies used for advancing cross-boundary conservation at various scales. We propose herein a landscape-scale adjoining conservation (LAC) approach for the protection and restoration of ecosystems across the administrative boundaries between protected areas and surrounding non-protected areas. The strategy of the LAC approach is to expand conservation areas by connecting isolated patches of important ecosystems or habitat outside of protected areas. Thus, the LAC approach can help alleviate the urgent problem whereby protected areas are too small and habitats are excessively fragmented [11]. As a case study, this paper applies the LAC approach to restore broadleaf Korean pine (BKP) mixed forest on the Changbai Mountain in northeastern China.

\section{Conservation on Changbai Mountain}

Abundant forest resources existed in northeastern China until the early 20th century [16]. The dominant forest type was primary BKP mixed forest [17], which was important not only as a habitat for numerous species of wildlife, but also as a precious source of hardwood and softwood timber. The BKP mixed forest typically contains three layers-tree, shrub, and herb layers. The tree layer is dominated normally by Pinus koraiensis, Quercus mongolica, Fraxinus mandshurica, Tilia mandshurica, and Acer mono; the shrub layer is dominated by Corylus mandshurica, Deutzia amurensis, and Acanthopanax senticosus, and the herb layer is dominated by Brachybotrys paridiformis, Lmpatiens noli-tangere, Athyrium multidentatum, and Carex callitrichos. In 1960, the Changbai Mountain Nature Reserve was established with the primary purpose of protecting BKP mixed forest. In 1980, the Changbai Mountain Nature Reserve was accepted as a biosphere reserve by UNESCO's Man and Biosphere Program. In 1986, the Changbai Mountain Nature Reserve was approved as a national-level nature reserve emphasizing forest protection. The well-protected BKP mixed forest within the Changbai Mountain Nature Reserve is one of the largest contiguous primary mixed forests in the temperate zone [18] and contains more plant species than other mixed forests [19] at similar latitudes.

However, accurate information about the spatial distribution and area of BKP mixed forest on the Changbai Mountain was not available until the advent of the Landsat remote sensing dataset in 1987 [20], which showed that the vegetation cover within the Changbai Mountain Nature Reserve was about $50 \%$ dark coniferous forest, whereas BKP forests covered only $27 \%$ of the reserve area and was 
mainly distributed in the northwest corner of the reserve. This pattern basically continued in the $8 \mathrm{~km}$ buffer zone outside the Changbai Mountain Nature Reserve. According to the Landsat data, the main vegetation types outside the Changbai Mountain Nature Reserve were coniferous and broad-leaved mixed forests, accounting for nearly a third of the total buffer area. The remaining third of the buffer area was covered by secondary forests [20].

Extensive logging outside the Changbai Mountain Nature Reserve officially started in the 1970s [21] and used the methods of small-area clear cutting. With an average area of $\sim 15$ ha, the cutting plots alternated along both sides of logging roads. Over time the forest landscape outside of the Changbai Mountain Nature Reserve has thus become more fragmented and BKP mixed forests have increasingly shrunk [22], producing both visual and functional green islands within the Changbai Mountain Nature Reserve. The BKP forest on the Changbai Mountain is rich in herbivores and carnivores, including wild boars (Sus scrofa), sika deer (Cervus nippon), bears (Ursus thibetanus, U. arctos), Siberian tigers (Panthera tigris ssp.altaica), and leopards (Panthera pardus orientalis). Although there was no logging within the Changbai Mountain Nature Reserve, the region, including the nature reserve and the surrounding areas, has shown no sign of tigers or leopards since the mid-1980s, and the population of surviving animals has significantly declined [23,24]. Li et al. [25] and Piao et al. [26] argue that the disappearance and decline of various animals on the Changbai Mountain are caused by habitat loss and fragmentation, which is the result of forest exploitation and land use change outside of the Changbai Mountain Nature Reserve.

The Changbai Mountain ecosystem as a whole is of great concern at the international level. In 1986, UNESCO placed a nature reserve of 132,000 ha in North Korea into the Man and Biosphere reserve system, thereby expanding the total area of the two nature reserves on the Changbai Mountain to 322,000 ha. The World Commission on East Asia's Steering Committee on East Asia has proposed a conceptual plan to establish the Changbai Mountain Ecological Corridor between connected protected areas in China and North Korea to promote species migration. Protection of the forest on the Changbai Mountain indeed means the protection of the forest ecosystem and the forest landscape [27]. Although logging has been banned in all natural forests in China since 2017 [28], the question of restoring low-quality secondary forests is a vital forest conservation issue that must be considered.

\section{Materials and Methods}

The LAC approach uses an integrated analysis of habitat features and landscape patterns. Both patch-level attribute data and landscape maps are used for prioritizing patches for efficient habitat restoration. Applying the LAC approach to forest landscapes typically involves site selection, focal statistics, prioritization, and efficiency assessment. Detailed procedures of the LAC approach are explained in the case study of the Changbai Mountain (Figure 1).

\subsection{Site Selection}

Based on the geographical position of the BKP mixed forests in the Changbai Mountain Nature Reserve and the range of elevations of the primary BKP mixed forest zone on the Changbai Mountain, we selected four forestry bureaus on the northwest slopes of the Changbai Mountain: Baihe, Lushuihe, Quanyang, and Songiianghe Forestry Bureaus (Figure 2). These four forestry bureaus are key forest enterprises on the Changbai Mountain and played important roles in the Chinese timber industry from the 1970s to the 1990s. Surrounding the Changbai Mountain Nature Reserve, the four forestry bureaus managed large areas of BKP mixed forests that used to be connected with the contiguous forest landscape containing the protected BKP mixed forests in the nature reserve. Over $97 \%$ of land use is forestland within the four forestry bureaus. The remaining $3 \%$ is primarily urban area (Figure 2). The conservation of BKP mixed forests by these four forestry bureaus is of great significance for preserving timber resources and protecting regional ecosystems. 


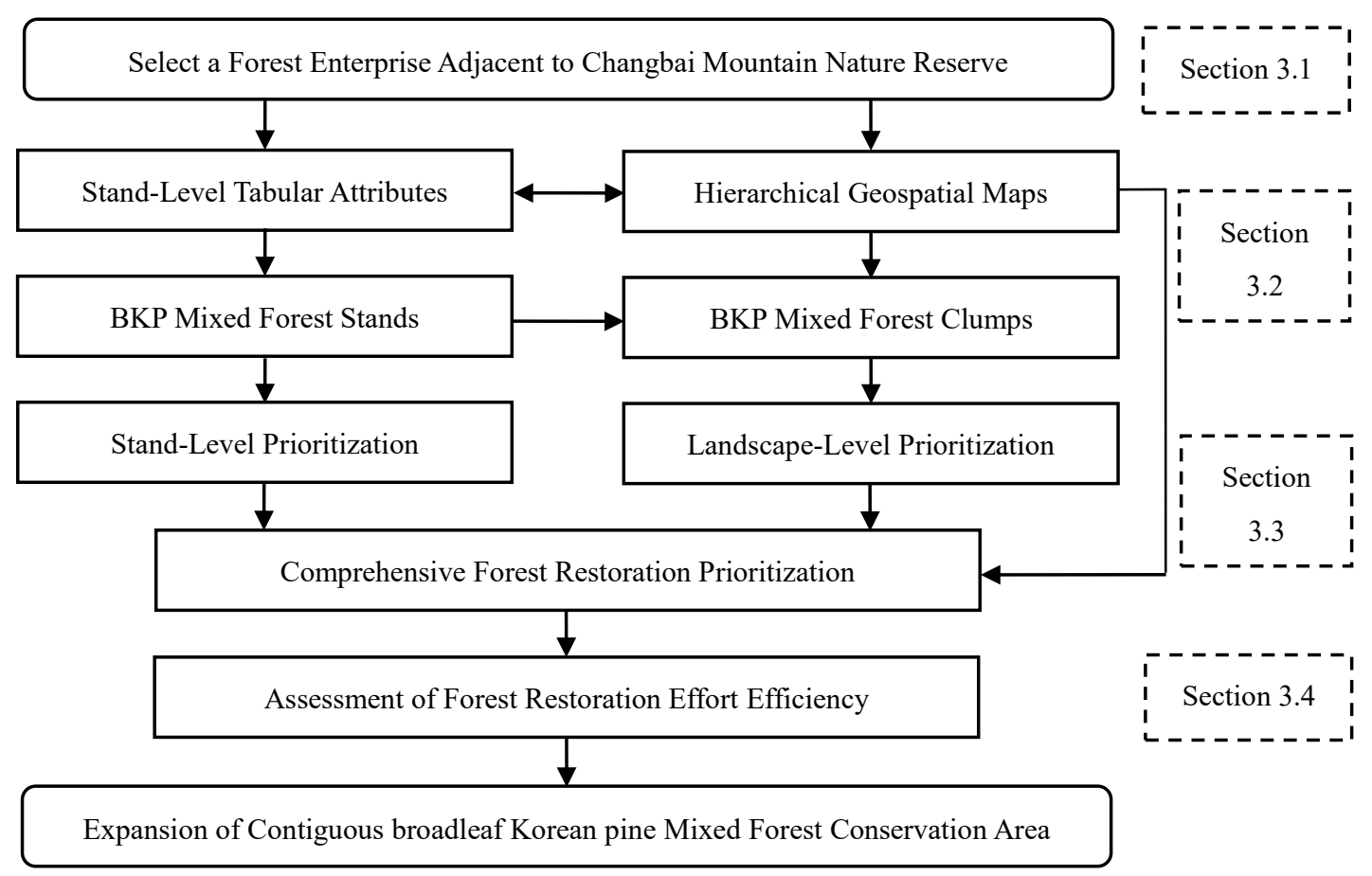

Figure 1. Flowchart for applying landscape-scale adjoining conservation (LAC) approach to forest conservation on Changbai Mountain.

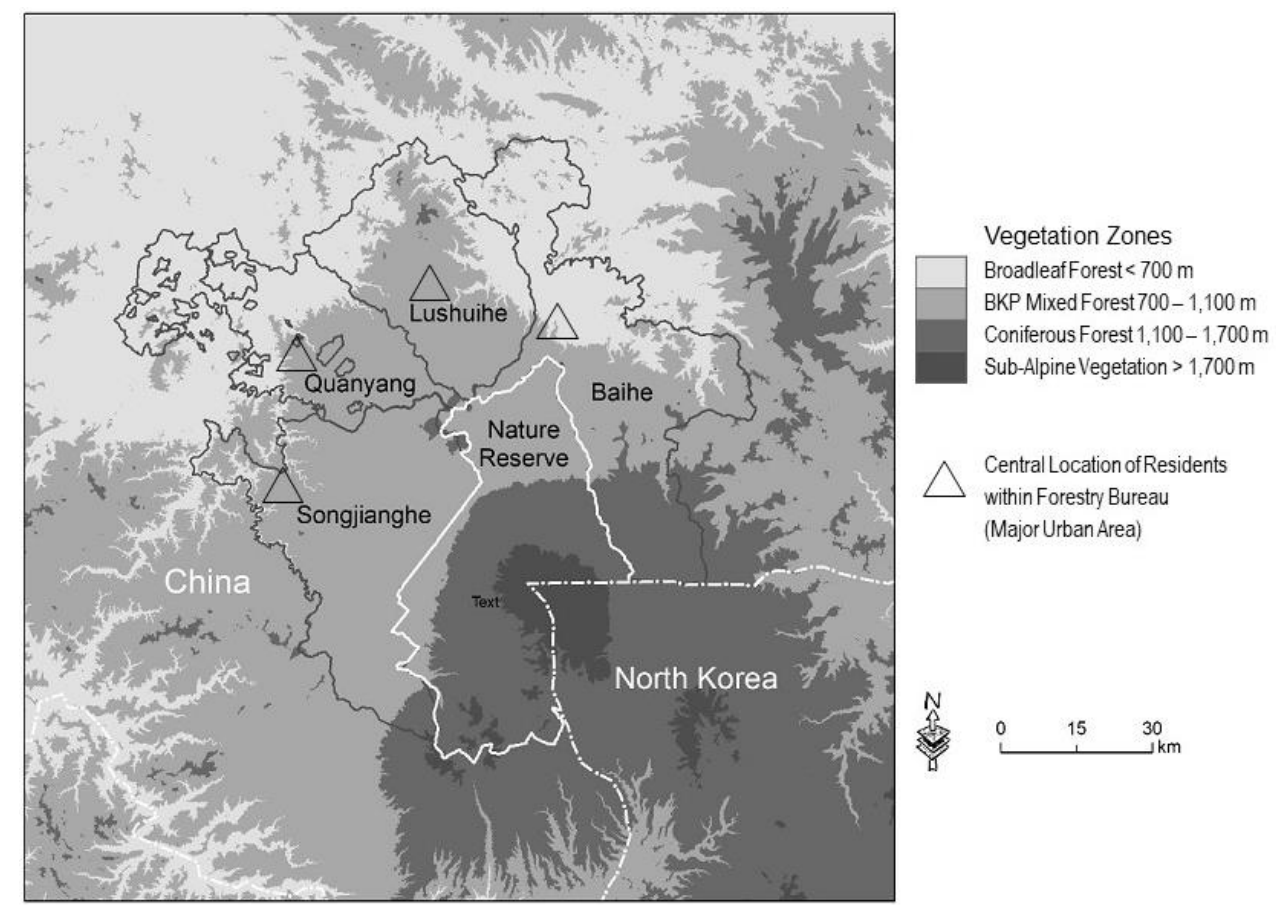

Figure 2. Location of four forest bureaus near the Changbai Mountain Nature Reserve selected for this study.

\subsection{Defining Habitat Clumps}

From each forest bureau, we used the latest forest-inventory data, which were collected between 2010 and 2013 [29]. The basic inventory unit is the sub-compartment and each inventory gave a 
sub-compartment map in ArcGIS format and a tabular datasheet in Excel format for each forestry bureau. The map and tabular data share common fields, including sub-compartment number (SCN), compartment number (CN), and forest farm name or number (FFN). To join the two datasets by using an ArcGIS function called joining tables, we created a unique identification (ID) for each sub-compartment within a forestry bureau. The ID is computed for the ArcGIS and Excel tables as follows:

$$
\mathrm{ID}=\mathrm{FFN} \times 1,000,000+\mathrm{CN} \times 10,000+\mathrm{SCN}
$$

Because the four forestry bureaus are located mostly below $1100 \mathrm{~m}$ in elevation, every sub-compartment contains broadleaf trees whenever the forest was naturally regenerated. A forest stand is called a "BKP mixed forest" if the given sub-compartment contains naturally regenerated Korean pine trees. We converted vector geographic-information-system (GIS) data into raster GIS data with a cell size of $100 \mathrm{~m}$ and did the focal statistics summation (FSS) by using $15 \times 15$ moving windows. As a result, the FSS' theoretical values range from 0 and 225. Based on the histogram of the FSS values within a forestry bureau, we classified the continuous FSS raster GIS data layers into a two-class thematic GIS data layers, where unity represents BKP mixed forest and zero represents all other. We then converted the thematic GIS into a vector GIS, resulting in clumps of BKP mixed forest.

The contiguous BKP mixed forest landscape within the Changbai Mountain Nature Reserve covers an area of approximately $20 \times 20 \mathrm{~km}$. To expand the BKP mixed forest protection equivalent to the existing protected BKP mixed forest landscape, we defined a $20 \mathrm{~km}$ zone outside the Changbai Mountain Nature Reserve as the conservation zone, and then further divided it into two sub-zones: A key conservation zone for areas within $10 \mathrm{~km}$ from the Changbai Mountain Nature Reserve and an ordinary conservation zone for areas 10 to $20 \mathrm{~km}$ from the Changbai Mountain Nature Reserve.

\subsection{Classifying Landscape Elements}

Based on the concept of habitat connectivity [30,31], we used stand- and landscape-level rules to classify sub-compartments into six different functional types:

Type 1: Contiguous habitat (habitat), including BKP mixed forests located inside BKP mixed forest clumps;

Type 2: Key BKP mixed forest corridor (key corridor), including BKP mixed forests outside BKP clumps in the key conservation zone;

Type 3: Ordinary BKP mixed forest corridor (ordinary corridor), including BKP mixed forests outside BKP clumps inside the ordinary conservation zone;

Type 4: Habitat gap (gap), including naturally regenerated forests other than BKP mixed forests inside BKP clumps;

Type 5: Habitat barrier (barrier), including man-made non-forest elements;

Type 6: Matrix, which includes all types of forests other than BKP mixed forests outside BKP clumps.

Landscape-element types 1-3 were set as prioritized protection targets and types 4-6 were set as prioritized restoration targets.

To accelerate the expansion of contiguous BKP mixed forest landscapes, active restoration measures must be applied to the prioritized restoration targets. With limited labor and financial resources, the restoration measures need to be prioritized by considering both landscape and stand conditions. Toward this end, we propose five levels of priority based on landscape- or stand-level considerations (see Table 1). The stand-level considerations include both timber sources and ecological conditions [32]. Thus, by summing the landscape-level score and the stand-level score, we obtain a ten-level evaluation system where unity corresponds to the lowest priority for restoration whereas 10 corresponds to the highest priority for restoration. 
Table 1. Numeralization of forest restoration priorities. One is lowest priority, 5 is highest priority.

\begin{tabular}{cc}
\hline Landscape-Level Forest Restoration Priorities & \\
\hline Young and mid-aged habitat gaps adjacent to key corridors & 5 \\
Young and mid-aged habitat gaps adjacent to ordinary corridors & 4 \\
Habitat barriers located in BKP mixed forest clumps & 3 \\
Matrix & 2 \\
Other forests located in BKP mixed forest clumps & 1 \\
\hline Stand-level forest restoration priorities & 5 \\
\hline Barren forestlands & 4 \\
Planted forests & 3 \\
forests & 2 \\
Young and middle-aged/near-mature broadleaf or coniferous & 1 \\
\hline
\end{tabular}

\subsection{Assessing the Effectiveness of Landscape Restoration}

The ultimate goal of using the quantitative criteria for forest restoration priorities is to improve the efficiency of forest restoration by promoting habitat connectivity. Ideally, an increase in contiguous habitat area would exceed the proportional increase in the total habitat area. We used Max Patch Area of Habitat (MPAH), which is one of the simplest landscape metrics ( $\mathrm{Li}$ and $\mathrm{Wu} 2004$ ), to quantify the largest contiguous habitat area. Assuming that the existing habitat is well protected, the successful restoration of habitat represents the newly gained habitat area $\left(\mathrm{HA}_{\text {new }}\right)$. We thus propose the following index called the Restoration Efficiency of Landscape Expansion (RELE):

$$
\mathrm{RELE}=\left(\mathrm{MPAH}_{2}-\mathrm{MPAH}_{1}\right) / \mathrm{HA}_{\text {new }} \text {, }
$$

where $\mathrm{MPAH}_{1}\left(\mathrm{MPAH}_{2}\right)$ is the MPAH before (after) restoration.

MPAH and $\mathrm{HA}_{\text {new }}$ refer to the same unit. For efficient landscape-restoration efforts, the value of RELE should be greater than unity. Greater values of RELE correspond to more efficient of landscape-restoration efforts.

\section{Results}

Several large-area BKP mixed forest clumps were found outside the Changbai Mountain Nature Reserve, but not all of them were in close proximity to the boundary of the nature reserve (Figure 3).

The majority of the large-area BKP mixed forest clumps are located within the $20 \mathrm{~km}$ conservation zone. A total of 174,936 ha falls within the $20 \mathrm{~km}$ conservation zone, which is comparable to the total forest area of the nature reserve (Table 2).

Within the $20 \mathrm{~km}$ conservation zone, the areas of the forestry bureaus Baihe and Songjianghe are clearly larger than the areas of Lushuihe and Quanyang (Figure 4 and Table 2). The size of the sub-compartments averaged over the four forestry bureaus is 10.6-11.5 ha. Of the six landscape components, the habitat sub-compartments are the largest (16.2 ha on average) and the barrier sub-compartments are the smallest ( 3.0 ha on average). The matrix is the dominant landscape component within the $20 \mathrm{~km}$ conservation zone, followed by habitat, and the key corridor and barrier have the smallest total areas.

Almost every forest stand outside the Changbai Mountain Nature Reserve has undergone a certain degree of disturbance and now requires restoration. If sub-compartments with the highest and second-highest restoration priorities are selected for restoration, only $4.0 \%$ of the total forest area or $5.4 \%$ of the total sub-compartments will be restored (Table 3). Of the four forestry bureaus, the most efforts would be made in Songjianghe and the least in Quanyang. However, the selected sub-compartments represent equally low fractions of the four forestry bureaus. If such prioritized 
restoration efforts were successful, the maximum patch area would increase by $46 \%$ for Baihe, $86 \%$ for Lushuihe, $26 \%$ for Quanyang, and $127 \%$ for Songjianghe (Table 4). Furthermore, RELE takes on values of 1.4, 3.9, 1.4, and 2.7 for Baihe, Lushuihe, Quanyang, and Songjianghe, respectively (Table 4).

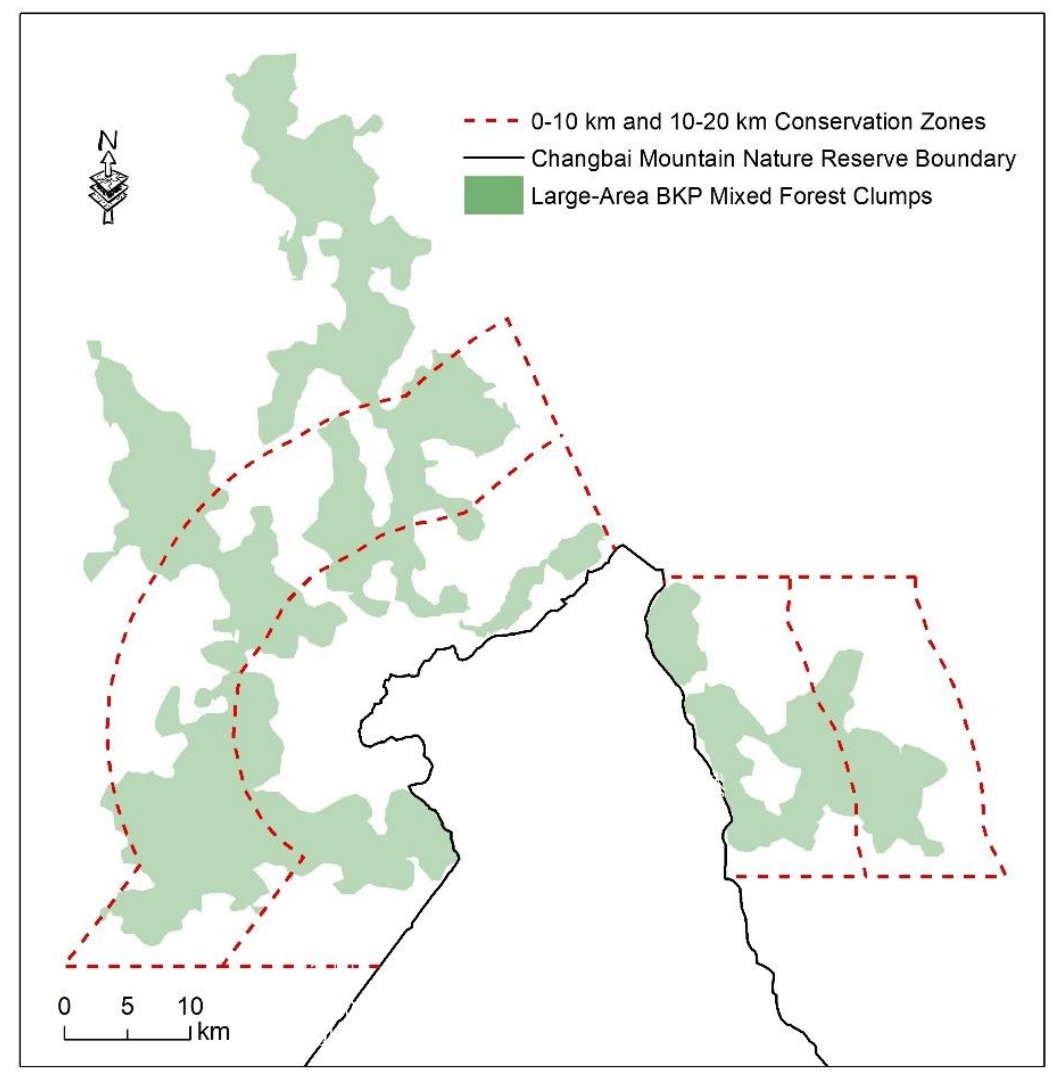

Figure 3. Distribution of large-area BKP forest clumps and the 20-km conservation zone.

Table 2. Summary of landscape components within $20 \mathrm{~km}$ conservation zone (see Figure 4).

\begin{tabular}{|c|c|c|c|c|c|c|c|}
\hline & & Habitat & $\begin{array}{c}\text { Key } \\
\text { Corridor }\end{array}$ & $\begin{array}{l}\text { Ordinary } \\
\text { Corridor }\end{array}$ & Gap & Barrier & Matrix \\
\hline \multirow{3}{*}{ Baihe } & Sub-Cpt. Counts & 882 & 120 & 294 & 1251 & 356 & 2350 \\
\hline & Total Area (ha) & 13,091 & 1247 & 4729 & 11,696 & 1250 & 25,175 \\
\hline & Mean Area (ha) & 14.8 & 10.4 & 16.1 & 9.3 & 3.5 & 10.7 \\
\hline \multirow{3}{*}{ Lushuihe } & Sub-Cpt. Counts & 777 & 186 & 221 & 442 & 660 & 1116 \\
\hline & Total Area (ha) & 13,010 & 2470 & 3003 & 4983 & 2721 & 13,034 \\
\hline & Mean Area (ha) & 16.7 & 13.3 & 13.6 & 11.3 & 4.1 & 11.7 \\
\hline \multirow{3}{*}{ Quanyang } & Sub-Cpt. Counts & 417 & 31 & 145 & 345 & 384 & 926 \\
\hline & Total Area (ha) & 7031 & 455 & 2020 & 3715 & 658 & 9951 \\
\hline & Mean Area (ha) & 16.9 & 14.7 & 13.9 & 10.8 & 1.7 & 10.7 \\
\hline \multirow{3}{*}{ Songjianghe } & Sub-Cpt. Counts & 1,026 & 102 & 77 & 1077 & 690 & 2,107 \\
\hline & Total Area (ha) & 17,141 & 1464 & 628 & 12,446 & 1540 & 21,478 \\
\hline & Mean Area (ha) & 16.7 & 14.4 & 8.2 & 11.6 & 2.2 & 10.2 \\
\hline \multirow{3}{*}{ Total } & Sub-Cpt. Counts & 3,102 & 439 & 737 & 3115 & 2090 & 6,499 \\
\hline & Total Area (ha) & 50,273 & 5636 & 10,380 & 32,840 & 6169 & 69,638 \\
\hline & Mean Area (ha) & 16.2 & 12.8 & 14.1 & 10.5 & 3.0 & 10.7 \\
\hline
\end{tabular}




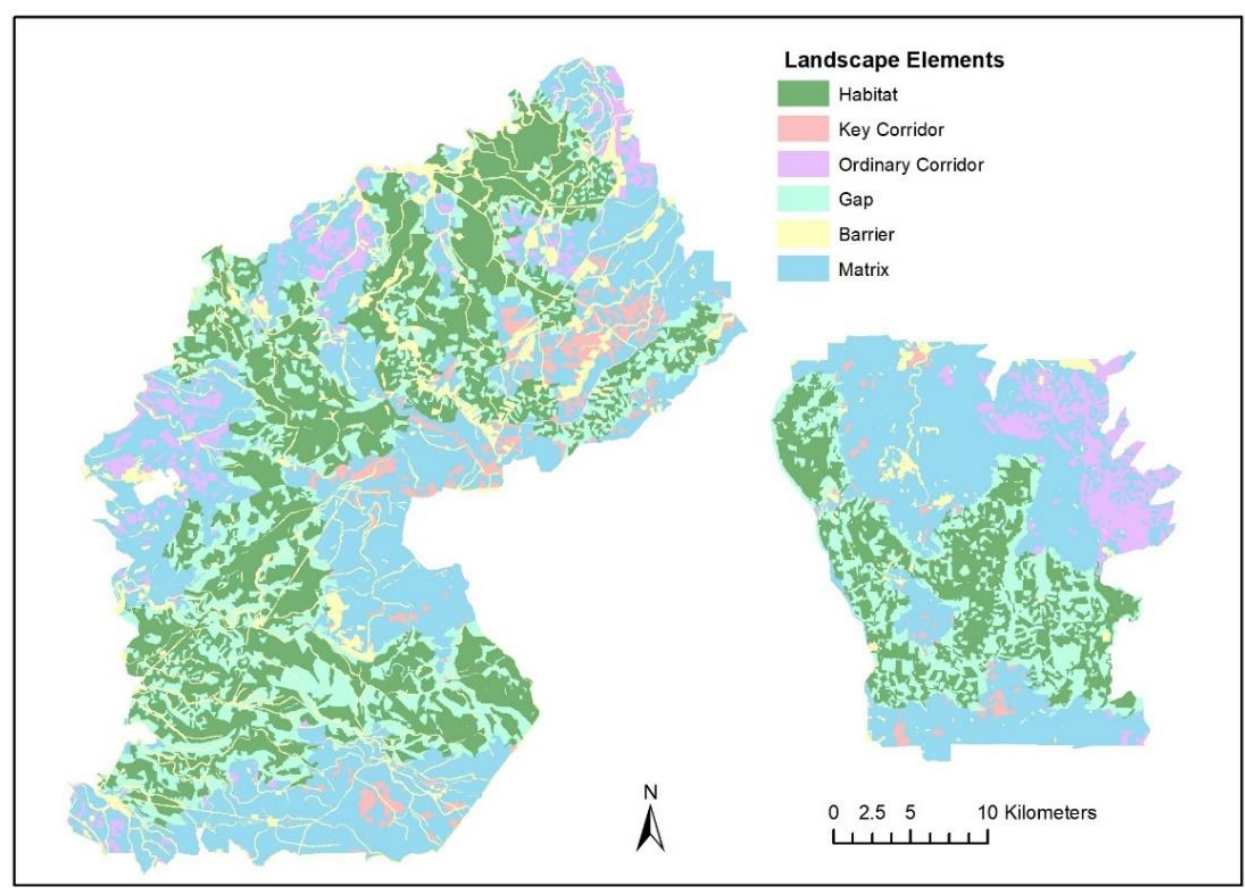

Figure 4. Distribution of landscape elements within $20 \mathrm{~km}$ conservation zone.

Table 3. Sub-compartments with highest and second-highest restoration priorities.

\begin{tabular}{|c|c|c|c|c|}
\hline & & $\begin{array}{c}\text { Entire } 20 \mathrm{~km} \\
\text { Conservation Zone }\end{array}$ & $\begin{array}{l}\text { Sub-Compartments } \\
\text { with Highest and } \\
\text { Second-Highest } \\
\text { Restoration Priority }\end{array}$ & $\begin{array}{l}\text { Percent of Highest and } \\
\text { Second-Highest } \\
\text { Restoration Targets } \\
\text { within } 20 \mathrm{~km} \text { Zone }\end{array}$ \\
\hline \multirow{2}{*}{ Baihe } & Sub-cpt. counts & 5253 & 196 & 3.7 \\
\hline & Total area (ha) & 57,188 & 1589 & 2.8 \\
\hline \multirow{2}{*}{ Lushuihe } & Sub-cpt. counts & 3402 & 187 & 5.5 \\
\hline & Total area (ha) & 39,221 & 1724 & 4.4 \\
\hline \multirow{2}{*}{ Quanyang } & Sub-cpt. counts & 2248 & 122 & 5.4 \\
\hline & Total area (ha) & 23,830 & 851 & 3.6 \\
\hline \multirow{2}{*}{ Songjianghe } & Sub-cpt. counts & 5079 & 337 & 6.6 \\
\hline & Total area (ha) & 54,697 & 2845 & 5.2 \\
\hline \multirow{2}{*}{ Total } & Sub-cpt. counts & 15,982 & 842 & 5.3 \\
\hline & Total area (ha) & 174,936 & 7009 & 4.0 \\
\hline
\end{tabular}

Table 4. Summary of restoration efficiency of landscape expansion after restoration of sub-compartments with highest and second-highest restoration priorities.

\begin{tabular}{cccccc}
\hline & TPRA (ha) & MPAH1 (ha) & MPAH2 (ha) & $\begin{array}{c}\text { MPAH } \\
\text { Change (\%) }\end{array}$ & RELE \\
\hline Baihe & 1589 & 4905 & 7177 & 46.3 & 1.4 \\
Lushuihe & 1724 & 7876 & 14,642 & 85.9 & 3.9 \\
Quanyang & 851 & 4398 & 5564 & 26.4 & 1.4 \\
Songjianghe & 2845 & 5953 & 13,538 & 127.4 & 2.7 \\
Overall & 7009 & 23,132 & 40,918 & 76.9 & 2.5 \\
\hline
\end{tabular}

Note: TPRA stands for Top-two Priority Restoration Area; MPAH stands for Max Patch Area of Habitat; RELE stands for Restoration Efficiency of Landscape Expansion. 


\section{Discussion}

Cost-efficient restoration techniques are required for the widespread degradation of natural ecosystems requires [33]. We propose to use the LAC approach when insufficient habitat is protected, when the area surrounding protected habitat is highly fragmented, and when insufficient resources for habitat restoration are available. These conditions are commonly associated with isolated protected areas in developing countries (e.g., Reference [34]). The LAC approach was tested by applying it to the Changbai Mountain and it proved to be useful for prioritizing the landscape-scale conservation efforts required in protected and managed forests.

Road networks within forest landscapes constitute major animal barriers on the Changbai Mountain and their negative effects on habitat connectivity need to be controlled [35]. One practical method of control is to convert roads into forests [36]. The raster GIS data structure used herein has a relatively large cell size, which may weaken the effect of roads on habitat fragmentation, which is consistent with road-to-forest conversions.

The results shown in Table 3 indicate that the total sub-compartments with highest and second-highest forest-restoration priority account for about $\sim 5 \%$ of forestlands. To actively manage these forestlands in the context of forest-landscape restoration represents a minimal forest-conservation effort. However, small efforts such as this can have big effects in terms of expanding contiguous habitat. Such effectiveness is quantified by using the RELE metric, which can facilitate the comparison of different forest restoration strategies and methods. In practice, Figures 3 and 4 provide guidelines for visually locating the most critical sub-compartments for forest restoration if resources are only available for restoring a fraction of the top-priority sub-compartments based on the quantitative criteria listed in Table 1.

In 2017, China released a new forest policy that enforces the complete protection of natural forests across the entire country [28]. This new forest policy is critically important to stop further fragmentation of BKP mixed forests on the Changbai Mountain. However, this protection alone is not enough to allow the rapid recovery of forest landscapes. The forest-restoration procedure discussed herein can play a complementary role by helping to improve the connectivity of forest habitat on the Changbai Mountain. Once the forest stands or sub-compartments are selected for restoration, they can be applied with various silvicultural measures, including tending, thinning, and planting special-purpose tree species [37].

Thus, the methodology of the LAC approach involves integrated analyses that considers both habitat quality and landscape pattern. The quality of forest habitat is characterized in terms of species composition and stand structure, and the forest-landscape pattern is quantified with various landscape metrics. Due to the nature of landscape fragmentation, the focal statistic is particularly useful for examining habitat clumps but its output is sensitive to parameterization (i.e., cell size) that requires analyst's experience. The procedure of priority numeralization is also experience driven but can be freely adjusted according local conservation considerations. Additional experiments are therefore required before applying LAC approach to other types of landscapes.

The LAC approach does not involve typical spatial planning and scenarios used in land use studies (e.g., References $[38,39]$ ) but may absorb these concepts to improve its applications. The purpose of the LAC approach was to increase the efficiency of landscape-scale contiguous habitat restoration, which was evaluated by using the RELE metric. The habitat in this study was the BKP mixed forest, which was the primary vegetation type in the study area but had undergone severe degradation and fragmentation for decades. The habitat restoration considers tree species composition, which indirectly reflected the temporal dynamics of the forest as previously suggested [40]. The ultimate goal of this habitat restoration is to recover contiguous primary BKP mixed forest landscapes. Thus ecological continuity will be promoted at this scale and will benefit native biodiversity conservation in the region [15], but its effects on the total species richness may be uncertain [41,42]. Nevertheless, The LAC protocol can be used without major modifications in forest areas covered by degraded primary forests. 
Author Contributions: J.B., Q.W., F.L., and L.T. worked together on designing research methodology; J.B. and Q.W. collected necessary data and conducted validation on ground; J.B. performed data analysis and wrote the first draft of the manuscript. F.L. supervised data analysis and manuscript writing; L.T. and Q.W. edited the manuscript.

Funding: This research received no external funding.

Acknowledgments: We would like to thank Baihe, Lushuihe, Quanyang, and Songjianghe Forestry Bureaus for providing us with forest inventory data and field assistance during our ground investigation.

Conflicts of Interest: The authors declare no conflict of interest.

\section{References}

1. Fried, E. Habitat protection-The key for wildlife management. Conservationist 1983, 37, 10-13.

2. Hansson, L.; Angelstam, P. Landscape ecology as a theoretical basis of nature conservation. Landsc. Ecol 1991, 5, 191-201. [CrossRef]

3. Franklin, J.F. Preserving biodiversity: Species, ecosystems, or landscapes? Ecol. Appl. 1993, 3, $202-205$. [CrossRef] [PubMed]

4. Andrén, H. Effects of habitat fragmentation on birds and mammals in landscapes with different proportions of suitable habitat: A review. Oikos 1994, 71, 355-366.

5. Saura, S.; Bertzky, B.; Bastin, L.; Battistella, L.; Mandrici, A.; Dubois, G. Protected area connectivity: Shortfalls in global targets and country-level priorities. Biol. Conserv. 2018, 219, 53-67. [CrossRef] [PubMed]

6. Bennett, A.F. Habitat corridors and the conservation of small mammals in a fragmented forest environment. Landsc. Ecol. 1990, 4, 109-122. [CrossRef]

7. Fahrig, L. Relative effects of habitat loss and fragmentation on population extinction. J. Wildl. Manag. 1997, 61, 604-610. [CrossRef]

8. Fardila, D.; Kelly, L.T.; Moore, J.L.; McCarthy, M.A. A systematic review reveals changes in where and how we have studied habitat loss and fragmentation over 20 years. Biol. Conserv. 2017, 212, 130-138. [CrossRef]

9. Hoekstra, J.M.; Boucher, T.M.; Ricketts, T.H.; Roberts, C. Confronting a biome crisis: Global disparities of habitat loss and protection. Ecol. Lett. 2005, 8, 23-29. [CrossRef]

10. Fischer, J.; Lindenmayer, D.B. Landscape modification and habitat fragmentation: A synthesis. Glob. Ecol. Biogeogr. 2007, 16, 265-280. [CrossRef]

11. Pouzols, F.M.; Toivonen, T.; Di Minin, E.; Kukkala, A.S.; Kullberg, P.; Kuusterä, J.; Lehtomäki, J.; Tenkanen, H.; Verburg, P.H.; Moilanen, A. Global protected area expansion is compromised by projected land-use and parochialism. Nature 2014, 516, 383-386. [CrossRef] [PubMed]

12. Sandwith, T.; Shine, C.; Hamilton, L.; Sheppard, D. Transboundary Protected Areas for Peace and Co-operation; IUCN: Gland, Switzerland; Cambridge, UK, 2001.

13. Lysenko, I.; Besancon, C.; Savy, C. Global List of Transboundary Protected Areas. Available online: http: / / www.unep-wcmc.org (accessed on 20 June 2018).

14. Schoon, M.L. Do Parks Harm More Than They Help? The Role of Peace Parks in Improving Robustness in Southern Africa. Available online: https://www.researchgate.net/profile/Michael_Schoon/publication/ 237598487_DO_PARKS_HARM_MORE_THAN_THEY_HELP_-_THE_ROLE_OF_PEACE_PARKS_IN_ IMPROVING_ROBUSTNESS_IN_SOUTHERN_AFRICA/links/0deec533ae962d5f9a000000/DO-PARKSHARM-MORE-THAN-THEY-HELP-THE-ROLE-OF-PEACE-PARKS-IN-IMPROVING-ROBUSTNESSIN-SOUTHERN-AFRICA.pdf (accessed on 18 May 2018).

15. Kark, S.; Tulloch, A.; Gordon, A.; Mazor, T.; Bunnefeld, N.; Levin, N. Cross-boundary collaboration: Key to the conservation puzzle. Curr. Opin. Environ. Sustain. 2015, 12, 12-24. [CrossRef]

16. Shao, G.F. Long-term field studies of old-growth forests on Changbai Mountain in Northeast China. Ann. For. Sci. 2011, 68, 885-887. [CrossRef]

17. Jia, X.; Ma, F.F.; Zhou, W.M.; Zhou, L.; Yu, D.P.; Dai, L.M. Impacts of climate change on the potential geographical distribution of broadleaved Korean pine (Pinus koraiensis) forests. Acta Ecol. Sin. 2017, 37, 464-473. (In Chinese) 
18. Jeffers, J.N.R. The importance of research in temperate forests. In The Temperate Forest Ecosystem. Proceedings of the International Symposium: Temperate Forest Ecosystem Management and Environment Protection, Jilin, China, 5-11 July 1986; pp. 9-11.

19. Barnes, B.V.; Xu, Z.B.; Zhao, S.D. Forest ecosystems in an old-growth pine-mixed hardwood forest of the Changbai Shan preserve in northeastern China. Can. J. For. Res. 1992, 22, 144-160. [CrossRef]

20. Shao, G.F.; Zhao, G.; Zhao, S.D.; Shugart, H.H.; Wang, S.X.; Schaller, J. Forest cover types derived from Landsat TM imagery for Changbai Mountain Area of China. Can. J. For. Res. 1996, 26, 206-216. [CrossRef]

21. Zhao, G.; Maclean, A.L.; Shao, G.F. Small-area clearcutting and landscape fragmentation in an old-growth forested area of Northeastern China. In Proceedings of the Society of American Foresters, Travers City, MI, USA, 19-23 September 1998; pp. 219-224.

22. Tang, L.N.; Shao, G.F.; Piao, Z.J.; Dai, L.M.; Jenkins, M.A.; Wang, S.X.; Wu, G.; Wu, J.G.; Zhao, J.Z. Forest degradation deepens around and within protected areas in East Asia. Biol. Conserv. 2010, 143, 1295-1298. [CrossRef]

23. Piao, Z.J.; Tang, L.N.; Swihart, R.K.; Wang, S.X. Human-wildlife competition for Korean pine seeds: Vertebrate responses and long-term implications for mixed forests on Changbai Mountain, China. Ann. For. Sci. 2011, 68, 911-919. [CrossRef]

24. Ma, L.; Qu, Y.; Sun, G.Q.; Wan, J.; Li, J.Q. Exploring conservation options in the broad-Leaved Korean pine mixed forest of the Changbai Mountain region. Mt. Res. Dev. 2015, 35, 171-179.

25. Li, Z.W.; Wu, J.G.; Kou, X.J.; Tian, Y.; Wang, T.M.; Mou, B.; Ge, J.P. Land use pattern and its dynamic changes in Amur tiger distribution region. Yingyong Shengtai Xuebao 2009, 20, 714-724. (In Chinese)

26. Piao, Z.J. Temperate forest animals on Changbai Mountain. For. Man 2016, 9, 18-31. (In Chinese)

27. Tang, L.N.; Li, A.X.; Shao, G.F. Landscape-level forest ecosystem conservation on Changbai Mountain, China and North Korea (DPRK). Mt. Res. Dev. 2011, 31, 169-175. [CrossRef]

28. Liu, K.; Liang, Y.; He, H.S.; Wang, W.J.; Huang, C.; Zong, S.; Wang, L.; Xiao, J.; Du, H. Long-Term Impacts of China's New Commercial Harvest Exclusion Policy on Ecosystem Services and Biodiversity in the Temperate Forests of Northeast China. Sustainability 2018, 10, 1071. [CrossRef]

29. Wang, X.C.; Wang, S.D.; Dai, L.M. Estimating and mapping forest biomass in northeast China using joint forest resources inventory and remote sensing data. J. For. Res. 2018, 29, 797-811. [CrossRef]

30. Hilty, J.; Lidicker, W.Z., Jr.; Merenlender, A.M. Corridor Ecology. Aust. Ecol. 2006, 32, 357.

31. Kindlmann, P.; Burel, F. Connectivity measures: A review. Landsc. Ecol. 2008, 23, 879-890. [CrossRef]

32. Bai, J.W.; Zhao, Y.; Shi, L.Y.; Li, F.R. Assessing forest sustainability trajectory with temporal changes in timber output and ecological reserve: The case of China. J. For. Res. 2018, 29, 171-176. [CrossRef]

33. Barbosa, J.M.; Asner, G.P. Prioritizing landscapes for restoration based on spatial patterns of ecosystem controls and plant-plant interactions. J. Appl. Ecol. 2017, 54, 1459-1468. [CrossRef]

34. Acquah, E.; Rollins, R.; Dearden, P.; Murray, G. Concerns and benefits of park-adjacent communities in Northern Ghana: The case of Mole National Park. Int. J. Sustain. Dev. World Ecol. 2017, 24, 316-327. [CrossRef]

35. Grant, A.S.; Nelson, C.R.; Switalski, T.A.; Rinehart, S.M. Restoration of native plant communities after road decommissioning in the rocky mountains: Effect of seed-mix composition on vegetative establishment. Restor. Ecol. 2015, 19, 160-169. [CrossRef]

36. Tarvainen, O.; Tolvanen, A. Healing the wounds in the landscape-Reclaiming gravel roads in conservation areas. Environ. Sci. Pollut. Res. 2016, 23, 13732-13744. [CrossRef] [PubMed]

37. Qi, L.; Wang, J.; Yu, D.P.; Dai, L.M.; Contrereas, M. Responses of regeneration and species coexistence to single-tree selective logging for a temperate mixed forest in eastern Eurasia. Ann. For. Sci. 2016, 73, 449-460. [CrossRef]

38. Gordon, A.; Simondson, D.; White, M.; Moilanen, A.; Bekessy, S.A. Integrating conservation planning and landuse planning in urban landscapes. Landsc. Urban Plan. 2009, 91, 183-194. [CrossRef]

39. Dorning, M.A.; Koch, J.; Shoemaker, D.A.; Meentemeyer, R.K. Simulating urbanization scenarios reveals tradeoffs between conservation planning strategies. Landsc. Urban Plan. 2015, 136, 28-39. [CrossRef] 
40. Rappaport, D.I.; Tambosi, L.R.; Metzger, J.P. A landscape triage approach: combining spatial and temporal dynamics to prioritize restoration and conservation. J. Appl. Ecol. 2015, 52, 590-601. [CrossRef]

41. Norden, B.; Dahlberg, A.; Brandrud, T.E.; Fritz, O.; Ejrnaes, R.; Ovaskainen, O. Effects of ecological continuity on species richness and composition in forests and woodlands: A review. Ecoscience 2014, 21, $34-45$. [CrossRef]

42. Humphrey, J.W.; Watts, K.; Fuentes-Montemayor, E.; Macgregor, N.A.; Peace, A.J.; Park, K.J. What can studies of woodland fragmentation and creation tell us about ecological networks? A literature review and synthesis. Landsc. Ecol. 2015, 30, 21-50. [CrossRef]

(C) 2018 by the authors. Licensee MDPI, Basel, Switzerland. This article is an open access article distributed under the terms and conditions of the Creative Commons Attribution (CC BY) license (http:/ / creativecommons.org/licenses/by/4.0/). 